\title{
In the Adult Hippocampus, Chronic Nerve Growth Factor Deprivation Shifts GABAergic Signaling from the Hyperpolarizing to the Depolarizing Direction
}

\author{
Laura Lagostena, ${ }^{1 \star}$ Marcelo Rosato-Siri, ${ }^{1 \star}$ Mara D’Onofrio, ${ }^{3}$ Rossella Brandi, ${ }^{3}$ Ivan Arisi, ${ }^{3}$ Simona Capsoni, ${ }^{3}$ \\ Jessica Franzot, ${ }^{1}$ Antonino Cattaneo, ${ }^{2,3}$ and Enrico Cherubini ${ }^{1}$ \\ ${ }^{1}$ Neuroscience Programme, International School for Advanced Studies, 34014 Trieste, Italy, ${ }^{2}$ Scuola Normale Superiore, Piazza dei Cavalieri, 56126 Pisa, \\ Italy, and ${ }^{3}$ European Brain Research Institute, 00143 Roma, Italy
}

\begin{abstract}
GABA, the main inhibitory transmitter in adulthood, early in postnatal development exerts a depolarizing and excitatory action. This effect, which results from a high intracellular chloride concentration $\left(\left[\mathrm{Cl}^{-}\right]_{\mathrm{i}}\right)$, promotes neuronal growth and synaptogenesis. During the second postnatal week, the developmental regulated expression of the cation-chloride cotransporter KCC2 accounts for the shift of GABA from the depolarizing to the hyperpolarizing direction. Changes in chloride homeostasis associated with high $\left[\mathrm{Cl}^{-}\right]_{\mathrm{i}}$ have been found in several neurological disorders, including temporal lobe epilepsy. Here, we report that, in adult transgenic mice engineered to express recombinant neutralizing anti-nerve growth factor antibodies (AD11 mice), GABA became depolarizing and excitatory. AD11 mice exhibit a severe deficit of the cholinergic function associated with an age-dependent progressive neurodegenerative pathology resembling that observed in Alzheimer patients. Thus, in hippocampal slices obtained from 6-month-old AD11 (but not wild-type) mice, the $\mathrm{GABA}_{\mathrm{A}}$ agonist isoguvacine significantly increased the firing of CA1 principal cells and, at the network level, the frequency of multiunit activity recorded with extracellular electrodes. In addition, in AD11 mice, the reversal of $\mathrm{GABA}_{\mathrm{A}}$-mediated postsynaptic currents and of GABA-evoked single-channel currents were positive with respect to the resting membrane potential as estimated in perforated patch and cell attached recordings, respectively. Real-time quantitative reverse transcription-PCR and immunocytochemical experiments revealed a reduced expression of mRNA encoding for Kcc2 and of the respective protein. This novel mechanism may represent a homeostatic response that counterbalances within the hippocampal network the Alzheimer-like neurodegenerative pathology found in AD11 mice.
\end{abstract}

\section{Introduction}

GABA, the main inhibitory transmitter in the adult CNS, at early developmental stages depolarizes and excites target cells through an outwardly directed flux of chloride (Ben-Ari et al., 1989; Cherubini et al., 1991; Ben-Ari, 2002). The intracellular chloride homeostasis is under control of two main $\mathrm{Cl}^{-}$cotransporters, the NKCC1 and KCC2 that enhance and lower high intracellular chloride concentration $\left(\left[\mathrm{Cl}^{-}\right]_{\mathrm{i}}\right)$, respectively (Blaesse et al., 2009). Because of the low expression of the KCC2 extruder at birth, chloride accumulates inside the neuron via NKCC1. The developmentally regulated expression of KCC2 toward the end of the first postnatal week is responsible for the shift of GABA from the depolarizing to the hyperpolarizing direction (Rivera et al., 1999). The depolarizing action of GABA enables the induction of

Received July 13, 2009; revised 0ct. 27, 2009; accepted Nov. 1, 2009.

This work was supported by Ministero Istruzione Universitá e Ricerca and American Alzheimer Association Grant 91238 (E.C.), Telethon Grant GGP 030416 (E.C., A.C.), the Italian Institute Technology (A.C.), and European Union Memories Grant 037831 (A.C.).

${ }^{*}$ M.R.-S. and L.L. contributed equally to this work.

Correspondence should be addressed to either Antonino Cattaneo or Enrico Cherubini, Neuroscience Programme, International School for Advanced Studies, Via Beirut 2-4,34014 Trieste, Italy, E-mail: antonino.cattaneo@sns.it or cher@sissa.it.

M. Rosato-Siri's present address: GlaxoSmithKline, Via A. Fleming 2, 37135 Verona, Italy.

DOI:10.1523/JNEUROSCI.3326-09.2010

Copyright $\odot 2010$ the authors $\quad 0270-6474 / 10 / 300885-09 \$ 15.00 / 0$ correlated network activity known to exert a critical control on the structural and functional refinement of synaptic connections (Kasyanov et al., 2004; Ben-Ari et al., 2007; Mohajerani et al., 2007).

Here we show that adult transgenic mice, engineered to express recombinant neutralizing anti-nerve growth factor (NGF) antibodies (AD11 mice) (Capsoni et al., 2000a; Ruberti et al., 2000), exhibit an alteration of chloride homeostasis in the hippocampus, which leads to a depolarizing shift of GABA from the hyperpolarizing to the depolarizing direction.

Chronic NGF deprivation in this model has been shown to produce important deficits of the cholinergic function paralleled with an age-dependent progressive neurodegenerative pathology resembling that found in Alzheimer's disease (AD) (Capsoni et al., 2000a). Adult AD11 mice display a neurodegenerative phenotype characterized by impairment in retention and transfer of spatial memory tasks associated with cholinergic atrophy, neuronal loss, tau hyperphosphorylation and insolubility, abnormalities of the neuronal cytoskeleton reminiscent of tangles (Capsoni et al., 2000a), $\beta$-amyloid (A $\beta$ ) plaques from the mouse $\beta$-amyloid precursor protein (APP) (Capsoni et al., 2002b), and deficit in cortical synaptic plasticity (Pesavento et al., 2002). In a previous study aimed at assessing the role of nicotine in long-term potentiation at Schaffer collateral-CA1 synapses in hippocampal slices from adult $\mathrm{AD} 11$ mice, we found that nicotine failed to boost 
synaptic plasticity when GABAergic transmission was blocked with bicuculline or gabazine (Rosato-Siri et al., 2006), indicating that GABAergic neurotransmission can "rescue" in these mice nicotine-induced modulation of synaptic plasticity. Among the possible mechanisms underlying these effects, we hypothesized a rearrangement of the GABAergic circuit and a shift of GABA from hyperpolarizing to depolarizing and excitatory. GABAinduced depolarization would remove the magnesium block from NMDA receptor channels, thus exerting a positive excitatory feedback on principal cells (Ben-Ari, 2002).

\section{Materials and Methods}

Anti-NGF AD11 mouse model. AD11 anti-NGF transgenic mice (Ruberti et al., 2000) express a recombinant version of the monoclonal antibody $(\mathrm{mAb}) \alpha \mathrm{D} 11$ that specifically recognizes and neutralizes NGF (Cattaneo et al., 1988; Covaceuszach et al., 2008). These mice were derived by linking the variable regions of light and heavy chains of the anti-NGF $\mathrm{mAb} \alpha \mathrm{D} 11$ to human $\kappa$ and $\gamma 1$ constant regions, yielding the chimeric human/rat antibody $\alpha \mathrm{D} 11$ (Ruberti et al., 1993), whose expression is transcriptionally driven by the human cytomegalovirus (CMV) early region promoter (Ruberti et al., 2000). Colonies of homozygous mice transgenic for the light chain gene only (CMV-VK $\alpha \mathrm{D} 11)$ or the heavy chain only (CMV-VH $\alpha$ D11) (VH11 mice) were established. Double transgenic anti-NGF AD11 mice were obtained by crossing single transgenic CMV-VK $\alpha \mathrm{D} 11$ and CMV-VH $\alpha \mathrm{D} 11$ mice. Each AD11 was individually tested by transgene genotyping (for $\mathrm{VH}$ and $\mathrm{VK}$ transgenes) and by measuring the level of chimeric rat/human anti-NGF antibodies in the serum, as described previously (Ruberti et al., 2000). In the group of 6-month-old AD11 mice used for the experiments, the serum antibody level varied between 20 and $176 \mathrm{ng} / \mathrm{ml}$. The AD11 mice were subdivided into two groups: group I, with "low" antibody levels, $<90 \mathrm{ng} / \mathrm{ml}(n=$ 21 ), and group II, with antibodies levels $>90 \mathrm{ng} / \mathrm{ml}(n=18)$. Experiments were performed from group II of animals (AD11 in the following), unless otherwise indicated. In wild-type (WT) animals (6 months old), antibody levels ranged between 2.8 and $4 \mathrm{ng} / \mathrm{ml}(3.5 \pm 0.2 ; n=7)$.

The mRNA for the VH and VK antibody chains was also determined in each AD11 by quantitative reverse transcription ( $\mathrm{qRT}$ )-PCR with the following primers, specific for the $\alpha \mathrm{D} 11$ variable region antibody chains: VH sense, AACAACAATGTGAAC; VH antisense, GGAGTGGATGGGAGGAGTC; probe, GGAAGAG; VK sense, AGCAGAAGCCAGGGAAATCT; VK antisense, TACCTTGCATACTGGGGTCC; probe, CAGCTCCT.

Mice were kept under a $12 \mathrm{~h}$ dark/light cycle, with food and water ad libitum. All experiments were performed in accordance with the European Community Council Directive of November 24, 1986 (86/609EEC) and were approved by the local authority veterinary service. All efforts were made to minimize animal suffering and to reduce the number of animals used.

Hippocampal slice preparation. Hippocampal slices from 6-month-old WT (strain B6SJL/F1) and AD11 transgenic mice were prepared according to the method described previously (Rosato-Siri et al., 2006). Briefly, animals were decapitated after being anesthetized with an intraperitoneal injection of urethane $(2 \mathrm{~g} / \mathrm{kg})$. The brain was quickly removed from the skull and placed in ice-cold artificial CSF (ACSF) containing the following (in mM): 215 sucrose, $3.5 \mathrm{KCl}, 1.2 \mathrm{NaH}_{2} \mathrm{PO}_{4}, 25 \mathrm{NaHCO}_{3}, 1.3 \mathrm{MgCl}_{2}$, $2 \mathrm{CaCl}_{2}$, and 25 glucose (saturated with $95 \% \mathrm{O}_{2}$ and $5 \% \mathrm{CO}_{2}$ ), $\mathrm{pH}$ 7.3-7.4. Transverse hippocampal slices $(300-400 \mu \mathrm{m}$ thick) were cut with a Vibratome (VT $1000 \mathrm{~S}$ ) and maintained at room temperature in ACSF containing $130 \mathrm{~mm} \mathrm{NaCl}$ instead of sucrose and bubbled with $95 \%$ $\mathrm{O}_{2}$ and $5 \% \mathrm{CO}_{2}$. After incubation for at least $1 \mathrm{~h}$, an individual slice was transferred to a submerged recording chamber and continuously superfused at $33-34^{\circ} \mathrm{C}$ with oxygenated ACSF at a rate of $4-5 \mathrm{ml} / \mathrm{min}$.

Electrophysiological recordings and data analysis. Spontaneous AMPAmediated EPSCs (sEPSCs) were recorded in the whole-cell configuration of the patch-clamp technique from CA1 pyramidal cells held at $-70 \mathrm{mV}$, close to the equilibrium potential for GABA $\left(E_{\mathrm{GABA}}\right.$ of $\left.-69 \mathrm{mV}\right)$, using the Axopatch 1D amplifier (Molecular Devices). Neurons were visualized using an upright microscope equipped with differential interference contrast optics and infrared video camera. Patch electrodes were pulled from borosilicate glass capillaries (Hingelberg) and were filled with an intracellular solution containing the following (in $\mathrm{mM}$ ): 125 Csmethanesulphonate, $10 \mathrm{CsCl}$, 10 HEPES, 0.3 EGTA, 2 MgATP, 0.3 NaGTP, and 5 QX-314 [2(triethylamino)- $N$-(2,6-dimethylphenyl) acetamine], $\mathrm{pH}$ adjusted to 7.2 with $\mathrm{CsOH}$. The resistance of the pipettes was 4-6 M $\Omega$. The whole-cell capacitance was fully compensated, and the series resistance $(10-20 \mathrm{M} \Omega$ ) was compensated at $75-80 \%$. The stability of the patch was checked by repetitively monitoring the input and series resistance during the experiment. Cells exhibiting $>15 \%$ changes in series resistance were excluded from the analysis. Membrane potential was corrected for the liquid junction potential of $\sim 10 \mathrm{mV}$.

In some experiments, GABA-mediated postsynaptic currents (GPSCs) were evoked in the presence of 6,7-dinitroquinoxaline-2,3-dione (DNQX) $(20 \mu \mathrm{M})$ and D-2-amino-5-phosphonopentanoate (D-AP-5) $(50 \mu \mathrm{M})$ via bipolar twisted NiCr-insulated electrodes (controlled via a stimulus isolation unit; Digitimer), positioned near the afferent fibers at the frequency of $0.05 \mathrm{~Hz}$. To measure the reversal of GPSCs $\left(E_{\mathrm{GPSCs}}\right)$, we used the gramicidin perforated patch (Kyrozis and Reichling, 1995), which preserves the anionic conditions of the recorded cells. In this case, the pipette solution contained the following: $140 \mathrm{~mm} \mathrm{KCl}, 1 \mathrm{mM} \mathrm{MgCl}_{2}, 10$ mM HEPES, 4 mм MgATP, $0.5 \mathrm{~mm}$ EGTA, and $80 \mu \mathrm{g} / \mathrm{ml}$ gramicidin D (purchased from Sigma). A $20 \mathrm{mg} / \mathrm{ml}$ stock of gramicidin in dimethylsulphoxide (DMSO) was prepared freshly ( $<2 \mathrm{~h}$ before recording) and sonicated. This was diluted with gramicidin-free solution, sonicated again for 20-30 s, and centrifuged. To facilitate the cell-attached formation, patch pipettes were dipped into, filled with a gramicidin-free solution by applying a negative pressure for 20-30 s, and then backfilled with a gramicidin-containing solution (seal resistance, $>3 \mathrm{G} \Omega$ ). After $\sim 30-40$ min from cell-attached formation, series resistance decreased and stabilized $\sim 30 \mathrm{M} \Omega$. The perforated patch condition was constantly monitored, and, in the case of membrane rupture, recording was discontinued. In fact, because of the high intracellular $\left[\mathrm{Cl}^{-}\right]$, the break of the membrane was associated with a clear change in membrane capacitance and a shift of $E_{\mathrm{GPSPs}}$ near $0 \mathrm{mV}$ (Tyzio et al., 2007). At the end of the experiments, bath application of gabazine $(10 \mu \mathrm{M})$ completely abolished the evoked responses, confirming that they were mediated by $\mathrm{GABA}_{\mathrm{A}}$ receptors.

To study the effects of isoguvacine on cell firing, cell-attached recordings were used. In this case, the patch pipette was filled with ACSF. Isoguvacine was applied from a puff pipette (intrapipette concentration of isoguvacine, $100 \mu \mathrm{M}$ dissolved in ACSF) positioned close the patched neurons via a pneumatic PicoPump [PV820 (World Precision Instruments); pulse duration, $0.5-1 \mathrm{~s}$; pressure, $2-6 \mathrm{psi}$.

Single-channel recordings were achieved in cell-attached mode. For $\mathrm{GABA}_{\mathrm{A}}$ single-channel events, patch pipettes were filled with solution containing the following: $120 \mathrm{~mm} \mathrm{NaCl}, 5 \mathrm{~mm} \mathrm{KCl}, 20 \mathrm{~mm}$ tetraethylammonium-Cl, $5 \mathrm{~mm}$ 4-aminopyridine, $0.1 \mathrm{~mm} \mathrm{CaCl}_{2}, 10$ mм $\mathrm{MgCl}_{2}, 10 \mathrm{~mm}$ glucose, $10 \mathrm{~mm}$ HEPES emisodium salt, and $3 \mu \mathrm{M}$ GABA.

The resting membrane potential (RMP) of CA1 pyramidal neurons was calculated from the reversal potential of NMDA-induced singlechannel currents evoked in cell-attached configuration. In these experiments, patch pipettes contained nominally $\mathrm{Mg}^{2+}$-free ACSF with NMDA $(10 \mu \mathrm{M})$ and glycine $(1 \mu \mathrm{M})$. For single-channel recordings, patch pipette resistance was 10-12 $\mathrm{M} \Omega$. Analysis of single-channel current versus potential $(I-V)$ relationship was achieved using Clampfit 10.1 software (Molecular Devices). The extrapolated reversal potential of single-channel recordings was estimated by fitting the $I-V$ plots with linear regression. Data were sampled at $30 \mathrm{kHz}$ with an analog-to-digital converter (Digidata 1322; Molecular Devices), filtered with a cutoff frequency of $1 \mathrm{kHz}$, and analyzed offline with Clampfit 10 (Molecular Devices). Single-channel experiments were sampled at $50 \mathrm{kHz}$ and filtered at a cutoff frequency of $2 \mathrm{kHz}$.

For recording of multiple unit activities (MUAs), micropipettes (resistance, $<3 \mathrm{M} \Omega$ ), filled with ACSF, were positioned near the pyramidal layer of the CA1 hippocampal region. MUAs were amplified using a DAM-800 differential amplifier (World Precision Instruments), lowpass filtered at $1 \mathrm{kHz}$, digitized at $10 \mathrm{kHz}$ (Digidata 1200; Molecular 
Devices), acquired with WinLTP software package (courtesy of W. W. Anderson, Bristol University, Bristol, UK), and analyzed offline using Clampfit 10.1 software (Molecular Devices).

Data are expressed as mean \pm SEM. Statistical comparison was performed using Student's $t$ test (paired or unpaired) or using the Wilcoxon's signed rank test, as appropriate. $p<0.05$ was taken as significant.

Drugs. SR-95531 [2-(3-carboxypropyl)-3-amino-6-(4-methoxyphenyl) pyridazinium bromide] (gabazine), DNQX, NMDA, GABA, D-AP-5, bumetanide, and isoguvacine were purchased from Tocris Bioscience. Stock solutions were made in distilled water or DMSO, divided into aliquots, and frozen at $-20^{\circ} \mathrm{C}$. Drugs were applied in the bath by gravity via a three-way tap system, by changing the superfusion solution to one differing only in its content of $\operatorname{drug}(\mathrm{s})$. The ratio of flow rate to bath volume ensured complete exchange within $2 \mathrm{~min}$.

$R N A$ isolation and real-time qRT-PCR. For qRT-PCR experiments, total RNA was extracted from all hippocampus, the medial septum, and the diagonal band of Broca of the basal forebrain. For mRNA analysis by real-time qRT-PCR, three AD11 and three age-matched control mice were used. Hippocampus and basal forebrain of the right hemisphere were dissected from the brains of freshly killed mice. All the tissue samples were stored in RNAlater (Qiagen). To control experimental variability connected to the circadian rhythms or stress condition induced by the laboratory environment, the animals were always killed at the same time during the day, without keeping cage mates in the laboratory. Total RNA was isolated from these brain areas, using Trizol (Invitrogen) and DNase, by Qiagen columns. RNA quantity was determined on a NanoDrop UV-VIS. Only samples with an absorbance ratio in the range $1.8<\mathrm{OD}_{260} / \mathrm{OD}_{280}<$ 2.0 were selected. Quality of RNA samples was checked for integrity with the Agilent BioAnalyzer 2100 (Agilent RNA 6000 nano kit): samples with an RNA Integrity Number index lower than 8.0 were discarded.

For qRT-PCR, each RNA sample was subjected to the two-step Applied Biosystems 7900HT Micro Fluidic Card protocol. The first-strand cDNA template was synthesized from $500 \mathrm{ng}$ of total RNA using random primers and Superscript III reverse transcriptase (Invitrogen) in a final volume of $100 \mu \mathrm{l}$. The micro fluid cards were run in the following PCR program: $50^{\circ} \mathrm{C}$ for $2 \mathrm{~min}, 94.5^{\circ} \mathrm{C}$ for $10 \mathrm{~min}$ and 40 cycles of $97^{\circ} \mathrm{C}$ for $30 \mathrm{~s}$, followed by $59.7^{\circ} \mathrm{C}$ for $1 \mathrm{~min}$. To measure the quantity of a given RNA species, the threshold cycles $(\mathrm{Ct})$ were monitored by the Applied Biosystems 7900HT Fast Real-Time PCR System. For quantification of gene expression changes, the $\Delta \Delta \mathrm{Ct}$ method was used to calculate relative fold changes normalized against the housekeeping gene ribosomal RNA 18S. Each data point is obtained from three AD11 and three age-matched control mice. Error bars are computed according to the SEM and the error propagation. The one-tailed $t$ test, assuming equal variances, was used to select significant expression values. The $F$ test was used to check the assumption of equal variances in AD11 and control mice. Statistical tests were performed using the R package. Genes, Ct values, and Applied Biosystems Assay ID used for qRT-PCR are listed in supplemental data (Table S1, available at www.jneurosci.org as supplemental material).

Immunohistochemistry. Immunohistochemistry for KCC2 was performed on brains from 6-month-old AD11 mice and age-matched control mice ( $n=6$ for each genotype). Briefly, mice were anesthetized with a $2 \%$ solution of 3,3,3-tribromethanol ( $1 \mathrm{ml} / 25 \mathrm{~g}$ body weight $)$ and perfused with ice-cold PBS followed by $4 \%$ paraformaldehyde/PBS. After postfixation in the same paraformaldehyde solution and cryoprotection in $30 \%$ sucrose, brains were sectioned and processed for immunohistochemistry using the anti-KCC2 antibody (1:100; Millipore Corporation), followed by a biotinylated anti-rabbit antibody (1:100; Vector Laboratories) and by chromogenic reaction using 3,3-diaminobenzidine $\mathrm{HCl}$ (Sigma-Aldrich), as described previously (Capsoni et al., 2009).

The intensity of the labeling was quantified using a Nikon 90i microscope connected to a video camera and the image analysis program NISElements (Nikon Instruments). Briefly, an intensity threshold was manually set up to detect, against the background and in fixed light conditions, all labeled pixels in control mice. After measuring, the same threshold was applied to AD11 mice sections. A mean of four sections per animal was analyzed on randomly chosen CA1 fields, using a $40 \times$ microscope objective.
Glutamate decarboxylase 65 (GAD65) immunoreactivity and its colocalization with $\beta$-amyloid was analyzed using, as primary antibodies, rabbit anti-GAD65 (1:100; Millipore Corporation) and the monoclonal antibody mAb 6E10 (1:100; Covance), respectively. The reaction was developed using the fluorescein/Oregon Green goat-conjugated Alex Fluor anti-rabbit and the cyanine 3-like donkey Alexa Fluor anti-mouse (Invitrogen).

\section{Results}

GABAergic signaling was studied in hippocampal slices obtained from 6-month-old anti-NGF AD11 mice and age-matched controls (WT). The levels of anti-NGF antibodies in AD11 mice are undetectable at birth, become readily detectable at approximately postnatal day 45 (P45), and stay high thereafter (Capsoni et al., 2000b; Ruberti et al., 2000). For this reason, AD11 mice are developmentally normal at birth, unlike $N G F^{-1-}$ knock-out mice (Crowley et al., 1994), which die in the first postnatal weeks as a result of severe developmental defects. The first signs of NGF deprivation-induced deficits are observed from P45 onward, concomitantly with the rise in anti-NGF antibody expression. The age of 6 months was chosen for these experiments because, at this age, the chronic exposure to anti-NGF antibodies has induced a neurodegeneration that is not yet fully blown and is still fully reversible by NGF (Capsoni et al., 2002a; De Rosa et al., 2005). Also, the previous study, from which the present one originated, was performed in 6-month-old AD11 mice (Rosato-Siri et al., 2006).

Previous work has shown that serum levels of anti-NGF antibodies reflect antibody levels in the brain. In adult AD11 mice, a certain degree of inter-individual variability in serum antibody levels is present. In the sample of 6-month-old AD11 mice used for this study, the serum antibody levels varied between 20 and $176 \mathrm{ng} / \mathrm{ml}$. This does not affect the overall neurodegenerative phenotype, as assessed by neuropathological endpoints (data not shown), but it may affect electrophysiological measurements at the single-cell level. For this reason, we arbitrarily divided 6-month-old AD11 animals into two groups: group I, with low antibody levels, $<90 \mathrm{ng} / \mathrm{ml}$, and group II, with antibodies levels $>90 \mathrm{ng} / \mathrm{ml}$. Experiments were performed from group II animals (AD11 in the following), unless otherwise indicated.

Cell-attached recordings, which affect neither the membrane potential nor the $\left[\mathrm{Cl}^{-}\right]_{\mathrm{i}}$, were used to study the functional properties of GABAergic signaling in CA1 principal cells in hippocampal slices obtained from AD11 mice and age-matched controls (WT). Application of the $\mathrm{GABA}_{\mathrm{A}}$ agonist isoguvacine from a puff pipette positioned close to the recorded neuron reduced cell firing in WT animals (from $0.39 \pm 0.1$ to $0.27 \pm 0.09 \mathrm{~Hz}$; seven slices from four different animals; $p<0.05$ ) (Fig. 1, top) and consistently increased the firing in AD11 mice (group II) (firing frequency varied from $0.19 \pm 0.06$ to $2.6 \pm 1.5 \mathrm{~Hz}$; eight slices from five different animals; $p<0.05$ ) (Fig. 1, middle). Because no differences in isoguvacine-induced increase in firing rate between AD11 male and female were detected, data were pooled together.

Interestingly, in group I AD11 mice, isoguvacine slightly decreased the firing (in three cells from two animals, firing frequency was $0.35 \pm 0.21$ and $0.3 \pm 0.18 \mathrm{~Hz}$, before and after isoguvacine, respectively) (Fig. 1, bottom), indicating that isoguvacine-induced increase in firing rate in group II AD11 mice was indeed related to a more effective neutralization of endogenous NGF, with higher levels of recombinant antibodies.

The excitatory effect of isoguvacine on cell firing was prevented by the $\mathrm{GABA}_{\mathrm{A}}$ receptor antagonists gabazine $(10 \mu \mathrm{M})$ or 
bicuculline $(10 \mu \mathrm{M})$, indicating that this effect was dependent on the activation of $\mathrm{GABA}_{\mathrm{A}}$ receptors (data not shown).

In another set of experiments from different animals, extracellular recordings were used to test whether, at the network level, isoguvacine was able to modify MUA. Extracellular signals were filtered to pass action potentials. As shown in the example of Figure 2, $A$ and $C$, in WT animals, application of isoguvacine $(100 \mu \mathrm{M})$ in the bath induced a significant reduction in the frequency of MUA with a loss of higher-amplitude events. Overall, in seven slices (from four different animals), a reduction in frequency from $22.1 \pm 5.1$ to $10.3 \pm 2.8 \mathrm{~Hz}$ was found. This led to a shift to the left of the cumulative probability amplitude distribution plot ( $p<$ 0.001, Wilcoxon's signed rank test). These effects were probably related to isoguvacine-induced membrane hyperpolarization and associated increase in membrane conductance. In contrast, in group II AD11 mice, isoguvacine significantly enhanced the frequency (but not the amplitude) of MUA from $16.3 \pm 5.6$ to $32.8 \pm 8.7 \mathrm{~Hz}$ (six slices from four different animals), an effect that was prevented by bicuculline. A shift to the right of the cumulative probability frequency plot was obtained ( $p<0.001$, Wilcoxon's signed rank test) (Fig. $2 B, D$ ). In control, differences in the frequency of MUA between WT and AD11 mice were not significant $(p=0.15)$. These results strongly suggest that, in chronically NGF-deprived animals, GABA exerts a depolarizing and excitatory action.

To further assess the contribution of the depolarizing and excitatory action of GABA to network activity, sEPSCs were recorded in whole-cell patch-clamp experiments from WT and AD11 mice at $-70 \mathrm{mV}$, which in our experimental conditions corresponds to the equilibrium potential for GABA $\left(E_{\mathrm{GABA}}\right)$. Bath application of bicuculline paradoxically reduced the frequency (but not the amplitude) of sEPSCs in AD11 mice, whereas it was ineffective in WT animals (supplemental Fig. S1, available at www.jneurosci. org as supplemental material).

To verify whether changes in GABAergic signaling were associated with possible modifications in the density of GABAergic terminals, immunolabeling experiments against GAD65, the synthetic enzyme for GABA, were performed. A higher number of GAD65-immunopositive puncta was found, by immunohistochemistry, in the stratum radiatum of the AD11 hippocampus than of the hippocampus of control mice (supplemental Fig. S2 D vs $A$, available at www.jneurosci.org as supplemental material). AD11 mice showed a higher intensity and number of GAD65 puncta, which appeared to be also enlarged (supplemental Fig. S2 D, available at www.jneurosci.org as supplemental material). Interestingly, in the AD11 stratum radiatum, the GAD65-

\section{Isoguvacine}

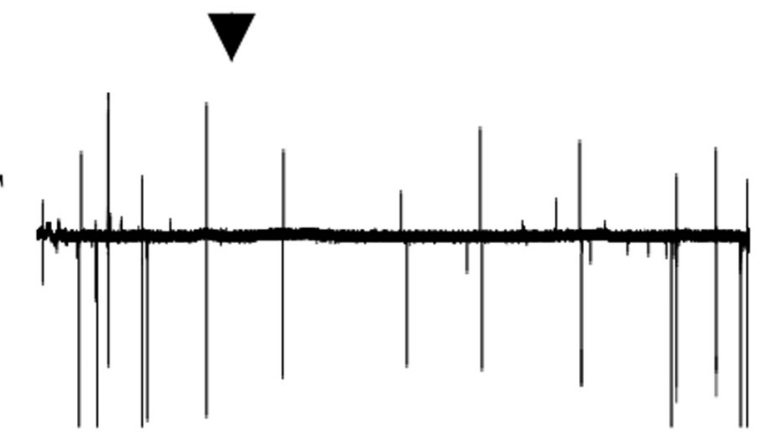

Figure 1. In $A D 11$ mice, pressure application of the $G A B A_{A}$ receptor agonist isoguvacine increases the firing rate of hippocampal CA1 principal cells. Responses of CA1 pyramidal cells (recorded in cell-attached mode) to pressure application of isoguvacine (100 $\mu \mathrm{M}$, arrows), in WT animals (top trace), in AD11 mice with high levels of NGF antibodies (group II, middle trace), and in AD11 mice with low levels of NGF antibodies (group I, bottom trace).

positive puncta colocalized with $\mathrm{A} \beta$ peptide (supplemental Fig. $\mathrm{S} 2 E, F$, available at www.jneurosci.org as supplemental material), whereas GAD65-labeled structures in the hippocampus of control mice did not show $\beta$-amyloid positivity (supplemental Fig. S2 $B, C$, available at www.jneurosci.org as supplemental material). The increased GAD65 immunoreactivity might suggest an increased GABAergic input to the CA1 than WT mice, although the colocalization of GAD65 with $\mathrm{A} \beta$ peptide suggests that these terminals are dystrophic.

As reported in a previous study, similar frequency and amplitude values of spontaneous action-potential-dependent (sGPSCs) and -independent (mini-GPSCs) GPSCs were found in principal cells of WT and AD11 mice (Rosato-Siri et al., 2006). Therefore, it seems likely that, in AD11 mice, the loss of NGF does not affect the release of GABA from stratum radiatum interneurons. 
A

WT

Control

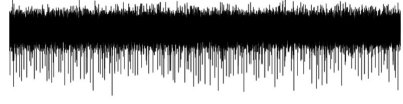

Isoguvacine

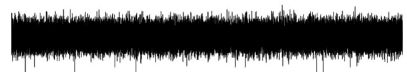

Wash

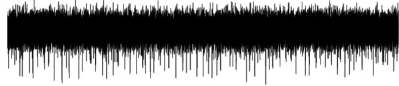

C

WT

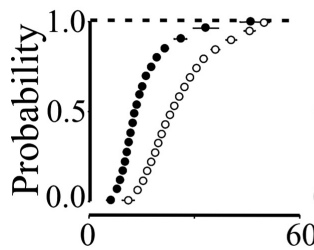

Amplitude $(\mu \mathrm{V})$ Frequency
B

AD11

Control

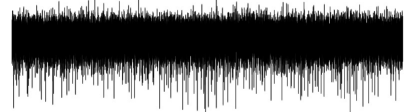

Isoguvacine

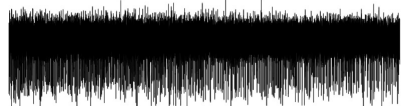

+ Bicuculline

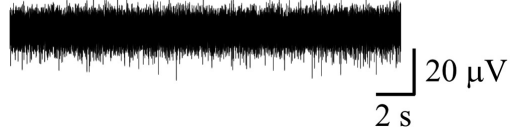

D

AD11

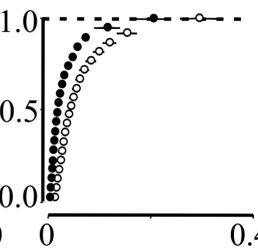

$0.4 \quad 0$

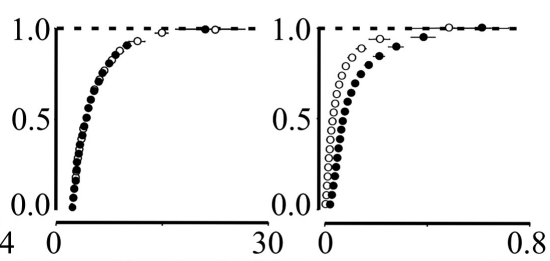

0.8

Figure 2. Changes in the effects of isoguvacine on MUA recorded from WT and AD11 mice. $A$, A brief application of isoguvacine in the bath to hippocampal slices from WT animals reduced the frequency of MUA and eliminated higheramplitude events in a reversible manner. $\boldsymbol{B}$, In group II AD11 mice, isoguvacine increased the frequency of MUA, an effect that was blocked by bicuculline $(10 \mu \mathrm{M})$. C, $\boldsymbol{D}$, Amplitude and frequency probability distribution plots obtained from WT $(\boldsymbol{C} ; n=7)$ and $\mathrm{AD} 11(\boldsymbol{D} ; n=6)$ mice in the absence (open circles) or presence (filled circles) of isoguvacine. Differences in amplitude (WT) and frequency (AD11) obtained in the presence of isoguvacine were significantly different from controls $(p<0.001$, Wilcoxon's signed rank test).

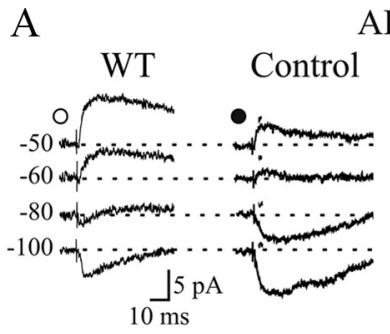

AD11

B
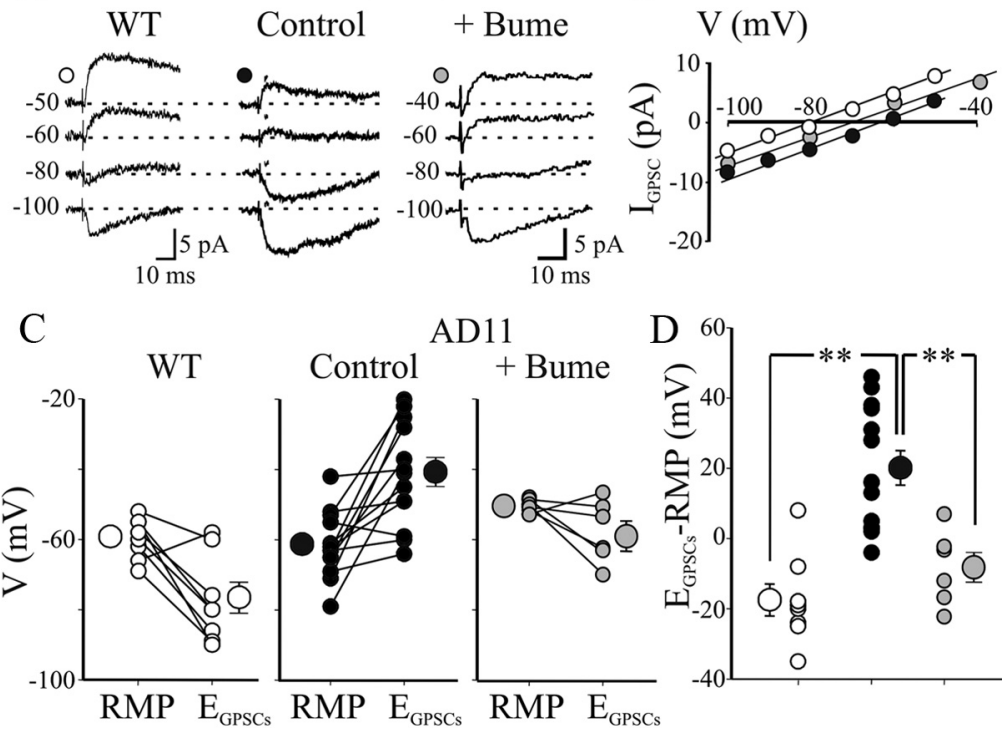

AD11
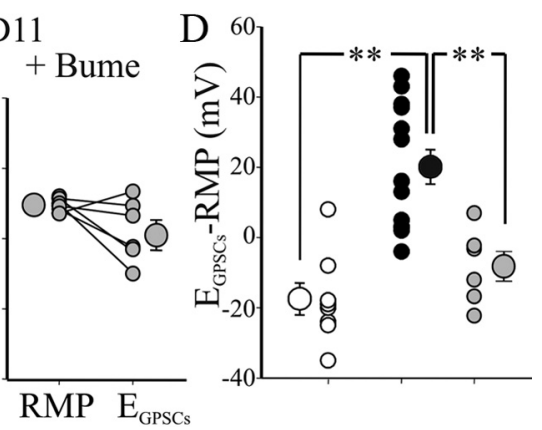

Figure 3. $E_{\mathrm{GPSCs}}$ is more positive in AD11 than in WT mice. A, Perforated patch recordings of cells in hippocampal slices from WT (white), AD11 (black), and AD11 exposed to bumetanide (gray). GPSCs were evoked by local stimulation of GABAergic interneurons in the presence of DNQX $(20 \mu \mathrm{m})$ and D-AP-5 $(50 \mu \mathrm{m})$. $\boldsymbol{B}$, Synaptic currents $\left(I_{\text {GPSCs }}\right)$ shown in $\boldsymbol{A}$ are plotted versus membrane potentials $\left(V_{\mathrm{m}}\right)$. C, Individual RMPs and $E_{\mathrm{GPSCs}}$ values in WT ( $n=15$; white), AD11 ( $n=20$; black), and AD11 exposed to bumetanide ( $n=6$; gray) slices. Larger symbols on the left and right refer to mean $\pm S E M$ values. $D$, Plot of the driving force for $\mathrm{GABA}_{\mathrm{A}}\left(E_{\mathrm{GABA}}-V_{\mathrm{m}}\right)$ in individual experiments from WT (white), AD11 (black), and AD11 exposed to bumetanide (gray) slices. Larger symbols are mean \pm SEM values. ${ }^{* *} p<0.001$.
The binding of GABA to $\mathrm{GABA}_{\mathrm{A}}$ receptors opens chloride-permeable channels. The resulting trans-membrane current can either depolarize or hyperpolarize the membrane according to $E_{\mathrm{GABA}}$ and to the RMP of the cell. Positive values of the driving force $\left(E_{\mathrm{GABA}}-\mathrm{RMP}\right)$ determine the depolarizing action of this neurotransmitter. Therefore, perforated patch recordings (to preserve the intracellular chloride gradient) were performed in voltage-clamp mode to analyze the reversal of $\mathrm{GABA}_{\mathrm{A}}$-mediated postsynaptic currents $\left(E_{\mathrm{GPSCs}}\right)$ in WT and $\mathrm{AD} 11$ mice. GPSCs were evoked in the presence of DNQX $(20 \mu \mathrm{M})$ and D-AP-5 $(50 \mu \mathrm{M})$. As shown in Figure 3, the reversal of GPSCs was $-77.3 \pm 4.3 \mathrm{mV}(n=8)$ and $-41.5 \pm$ $4.1 \mathrm{mV}(n=13)$ in WT and AD11, respectively (Fig. $3 A, B$ ). The $E_{\mathrm{GPSCs}}$ values obtained from AD11 mice were positive with respect to the resting membrane potentials and were significantly different from those detected in WT animals $(p<0.001)$ (Fig. 3C). The driving force for GABA ( $\left.E_{\mathrm{GPSCs}}-\mathrm{RMP}\right)$ was negative in WT $(-17.7 \pm 4.5 \mathrm{mV})$ and positive $(20.1 \pm 4.9 \mathrm{mV} ; p<0.001)$ in AD11 mice (Fig. 3D).

To see whether accumulation of chloride inside the cell via the cation-chloride cotransporter NKCC1 was responsible for the depolarizing action of GABA, slices from $\operatorname{AD} 11$ mice $(n=6$; four animals) were incubated for 30-50 min with bumetanide $(10 \mu \mathrm{M})$, a selective inhibitor of NKCC1 (Dzhala et al., 2005; Sipilä et al., 2006). In all cells tested, bumetanide caused a shift of $E_{\mathrm{GPSCs}}$ toward more negative values (more negative with respect to the RMP). On average, in six cells, $E_{\mathrm{GPSCs}}$ was $-61 \pm 4 \mathrm{mV}$ (a value significantly different from that obtained in the absence of bumetanide; $p<0.05$ ) (Fig. $3 A-D$, gray symbols), indicating that, in these cells, NKCC1 was regularly expressed and functional.

Although perforated patch experiments have revealed differences in $E_{\mathrm{GPSCs}}$ between WT and AD11 mice, this technique may introduce some errors (Tyzio et al., 2003). To overcome this problem, we carefully measured $E_{\mathrm{GABA}}$ and $V_{\mathrm{m}}$ in both WT and AD11 mice with noninvasive cell-attached recordings. Single NMDA channels were used as voltage sensors to measure $V_{\mathrm{m}}$ (concentration of NMDA into the patch pipette was $10 \mu \mathrm{M}$ ). The rationale is that currents through NMDA channels reverse near $0 \mathrm{mV}$ and therefore at the pipette potential $\left(V_{\mathrm{p}}\right)$ equal to $V_{\mathrm{m}}$. Figure $4 A$ shows an example of single-channel NMDA currents at two 
different $V_{\mathrm{p}}$. The extrapolated reversal potential obtained in five cells by plotting the mean amplitude of single-channel NMDA currents versus different values of $V_{\mathrm{p}}$ was $-75.3 \mathrm{mV}$ in $\mathrm{WT}$ and $-76.2 \mathrm{mV}$ in $\mathrm{AD} 11$ mice $(n=6)$ (Fig. $4 B)$. $E_{\mathrm{GABA}}$ was estimated in cell-attached recordings of single $\mathrm{GABA}_{\mathrm{A}}$ channels, which affect neither $E_{\mathrm{GABA}}$ nor $V_{\mathrm{m}}$ (concentration of GABA into the pipette was $3 \mu \mathrm{M})$. Singlechannel currents reversed polarity at -76 $\mathrm{mV}$ in WT $(n=8)$ and at $-56 \mathrm{mV}$ in AD11 $(n=10)$, respectively (these two values correspond to $\left[\mathrm{Cl}^{-}\right]_{\mathrm{i}}$ values of $\sim 9.6$ and $\sim 20.3 \mathrm{~mm}$ in $\mathrm{WT}$ and AD11, respectively) (Fig. $4 C, D$ ).

These results indicate that, in adult AD11 mice, the driving force for GABA is depolarizing. The more depolarizing potential measured with the perforated patch observed in both transgenic and WT animals can be at least in part attributable to a short-circuit effect of the leak through the contact between the pipette and the membrane (Tyzio et al., 2003).

In a recent study from immature neocortical neurons (Rheims et al., 2008), the depolarizing and excitatory action of GABA was found to be associated with modifications in intrinsic excitability ( $V_{\mathrm{m}}$ and spike threshold) of deep layer neurons. This combined action led to spontaneous coherent network-driven oscillations. To see whether similar changes occur in AD11 mice, we measured spike threshold in WT and AD11 mice. No significant differences in $V_{\mathrm{m}}$ (see Figs. 3, 4) and spike threshold were detected between the two groups of animals (the mean spike threshold value was $42 \pm 0.7$ and $44 \pm 0.5 \mathrm{mV}$ in WT and AD11 mice, respectively; $p=0.06 ; n=5$ each; data not shown), indicating that, in adult NGF-deprived mice, the excitatory action of GABA is not associated with changes in intrinsic neuronal excitability.

In the developing hippocampus, the cation-chloride cotransporter NKCC1 appears to be the main $\mathrm{Cl}^{-}$uptake mechanism responsible for the depolarizing action of GABA (Rohrbough and Spitzer, 1996; Plotkin et al., 1997; Fukuda et al., 1998; Sun and Murali, 1999; Li et al., 2002; Yamada et al., 2004; Rivera et al., 2005; Sipila et al., 2006; Blaesse et al., 2009). The developmental increase in KCC2 expression, and in particular the KCC2b isoform, is responsible for the developmental increase in neuronal $\mathrm{Cl}^{-}$extrusion and for the ontogenetic shift of GABA from the depolarizing to the hyperpolarizing direction (Rivera et al., 1999; Yamada et al., 2004). To correlate the observed depolarizing shift in synaptic responses to GABA observed in AD11 mice with alterations in gene expression, experiments were undertaken to evaluate the expression of selected mRNAs known to influence chloride homeostasis in the hippocampus ( $\mathrm{Nkcc1}$ and $\mathrm{Kcc} 2$ ). We also evaluated the expression of nicotine acetylcholine receptors (nAChRs), because nicotinic cholinergic receptor activity has been shown to drive maturation of GABAergic signaling (Liu et al., 2006).

The expression of the cation-chloride cotransporters NKCC1 and KCC2 mRNAs (Slc12a2 and Slc12a5) and of the $\alpha 3, \alpha 4, \alpha 7$, $\beta 2$, and $\beta 4$ subunits nAChRs (Chrna3, Chrna4, Chrna7, Chrnb2, and Chrnb4) was comparatively evaluated by real-Time qRT-

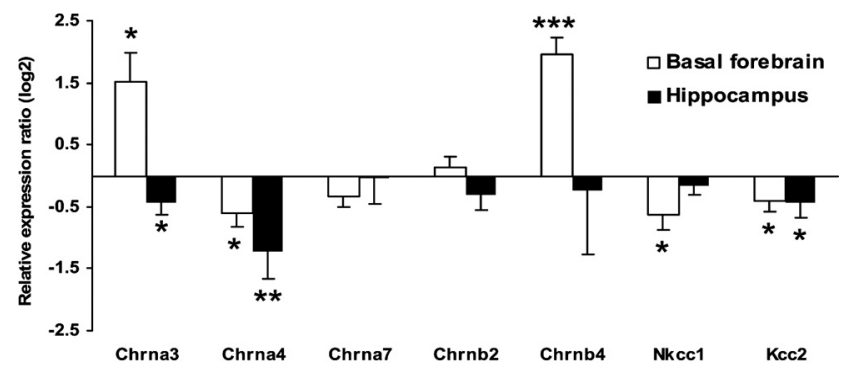

Figure 5. mRNA expression analysis of nicotinic receptors and cation-chloride cotransporters, by real-time qRT-PCR. These experiments were performed in the basal forebrain and hippocampus of six mice, three AD11 mice and three age-matched control mice at 6 months of age, for selected genes: five subunits of the nicotinic cholinergic receptors $(\alpha 3, \alpha 4, \alpha 7, \beta 2$, and $\beta 4)$ and the cation-chloride cotransporters $\mathrm{Nkcc} 1$ and $\mathrm{Kcc} 2$. Error bars are computed according to the SEM and error propagation. ${ }^{*} p<0.05,{ }^{* *} p<0.01,{ }^{* * *} p<0.001$.

PCR, in mRNA extracted from all hippocampus, the medial septum, and the diagonal band of Broca of the basal forebrain of 6-month-old AD11 mice (six mice, three AD11 and three agematched control mice). In accordance with electrophysiological data supporting an alteration of chloride homeostasis, a significant downregulation of the KCC2 mRNAs was found in the hippocampus, whereas the expression of the chloride-importing NKCC1 cotransporter was virtually unchanged (Fig. 5) (supplemental Table S1, available at www.jneurosci.org as supplemental material).

In addition, a downregulation of all nicotinic receptor subunits (except the Chrna7 subunit, which was virtually unchanged) was detected in the hippocampus. A downregulation of nicotinic receptor subunits was also observed in the basal forebrain (with the exception of the $\alpha 3$ and $\beta 4$ subunits, whose expression was increased) (Fig. 5) (supplemental Table S1, available at www.jneurosci.org as supplemental material). It is likely that the upregulation of $\alpha 3$ and $\beta 4$ subunits reflects a compensatory 

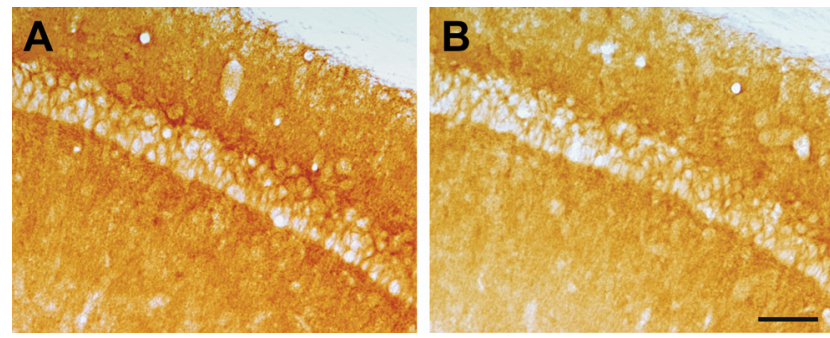

Figure 6. $\mathrm{KCC} 2$ protein is downregulated in the hippocampus of the AD11 mice. Immunohistochemistry of the CA1-CA2 region of the hippocampus with anti-KCC2 antibodies show a decreased labeling in $A D 11$ mice $(\boldsymbol{B})$, with respect to the hippocampus of age-matched control mice $(\boldsymbol{A})$. Scale bar, $100 \mu \mathrm{m}$.

mechanism. The one-tailed $t$ test, assuming equal variances, was used to select significant expression values. The $F$ test was used to check the assumption of equal variances in AD11 and control mice. Error bars are computed according to the SEM and error propagation (Fig. 5).

The lower expression of KCC2 in the hippocampus of AD11 mice was confirmed at the protein level by immunohistochemistry. Indeed, a marked decrease of KCC2 expression was observed in the hippocampus of AD11 mice (Fig. $6 B$ ), with respect to the hippocampus of age-matched controls (Fig. $6 \mathrm{~A}$ ). The quantification of the labeling intensity showed a value equal to $150 \pm 18$ pixels for control mice and $4.0 \pm 0.3$ pixels for AD11 mice. Thus, a statistically significant difference in the expression level of KCC2 protein exists between the two groups of mice $(p<0.05$, paired $t$ test) (Fig. $6 A, B$ ).

\section{Discussion}

GABA, the main inhibitory transmitter in the brain, during postnatal development or in particular conditions, including epilepsy (Cohen et al., 2002; Huberfeld et al., 2007), axonal injury (Nabekura et al., 2002), trauma (van den Pol et al., 1996), neuropathic pain (Coull et al., 2005), and inflammatory hyperalgesia and allodynia (Funk et al., 2008), becomes depolarizing and excitatory. This effect depends on a reverse chloride gradient after alterations in intracellular chloride homeostasis. This is mainly controlled by the cation-chloride cotransporters KCC2 and $\mathrm{NKCC1}$, which play a key role in regulating the electrochemical gradient required for the hyperpolarizing action of GABA (Blaesse et al., 2009). Here, we demonstrate that the expression of KCC2, the main chloride extruder selectively expressed in CNS neurons, is under the influence of NGF. Thus, in adult AD11 mice, the depolarizing action of GABA was found to be related to the level of anti-NGF antibodies present in the serum, indicating that chronic NGF neutralization is a condition that allows switching on a genetic program, which recapitulates that occurring during postnatal development. This would lead to a downregulation of KCC2 expression and a shift of GABA from the hyperpolarizing to the depolarizing direction. In the CNS, two functionally distinct KCC2 isoforms, the KCC2a and KCC2b, have been characterized (Uvarov et al., 2007). Although we do not know whether, in AD11 mice, chronic NGF deprivation affects both isoforms, the depolarizing and excitatory responses to GABA found in the present experiments suggest that the KCC2b isoform is downregulated.

The depolarizing effect of GABA was dependent on the positive value of the driving force for this neurotransmitter (the difference between $E_{\mathrm{GABA}}$ and the resting membrane potential $V_{\mathrm{m}}$ ) as estimated in cell-attached recordings of single $\mathrm{GABA}_{\mathrm{A}}$ and
NMDA receptor channels, which affect neither $E_{\mathrm{GABA}}$ nor $V_{\mathrm{m}}$. In AD11 mice, GABA action was not only depolarizing but also excitatory because, at the network level (experiments with MUA) or in cell-attached recordings, isoguvacine, a GABA agonist, was able to increase cell firing. The excitatory effect of GABA at the network level was further supported by the observation that bicuculline was able to paradoxically reduce the frequency of spontaneous action potential-dependent EPSCs. This effect may involve a major reorganization of the GABAergic circuitry within the hippocampal network. Thus, changes in $\mathrm{GABA}_{\mathrm{A}}$-mediated signaling at postsynaptic sites may occur in parallel with presynaptic modifications of GABAergic innervation. In the present experiments, the increased density of GAD-positive puncta on CA1 principal cells in the hippocampus from AD11 mice fully supports this assumption. However, structural changes were not accompanied with presynaptic modifications of GABA release, as revealed by previous reported electrophysiological experiments (Rosato-Siri et al., 2006). Although the reason for this discrepancy is presently unknown, we cannot exclude the possibility that amyloid $\mathrm{A} \beta$ peptide accumulation in close vicinity of GABAergic terminals renders them not functional. A similar remodeling of the inhibitory entorhinal-hippocampal circuit has been detected in transgenic mice overexpressing a mutant form of human APP (Palop et al., 2007). Although in this study the direction of GABA signaling was not determined, APP transgenic mice exhibited spontaneous nonconvulsive seizures activity. This is of interest in view of the higher incidence of seizures in $\mathrm{AD}$ patients with respect to age-matched reference population, an effect that may contribute to cognitive deficits in $\mathrm{AD}$ (Amatniek et al., 2006; Palop and Mucke, 2009). In AD11 mice, the occurrence of spontaneous seizures was never detected, although their potential occurrence has been carefully monitored over time, in a large number of animals in the colony (S. Capsoni and A. Cattaneo, personal communication). However, whether changes in GABAergic signaling and sprouting makes these animals more prone to experimentally induced seizures, it remains to be elucidated.

It has been demonstrated recently that maturation of GABAergic signaling is driven by endogenous nicotine cholinergic activity (Liu et al., 2006). The mechanism is likely to involve calcium influx through nAChRs. This would promote maturation of the chloride gradient by increasing the expression of the cation-chloride cotransporter KCC2, making the equilibrium potential for chloride currents more negative. Interestingly, in the present experiments, the reduced expression of Kcc2 mRNA and protein was associated with a severe impairment of cholinergic function not only in the hippocampus but also in the basal forebrain cholinergic neurons. These neurons are known to critically depend on NGF for their survival and differentiation (Hefti, 1986; Li et al., 1995; Molnar et al., 1998; Cattaneo et al., 1999; Debeir et al., 1999) and previous studies from AD11 mice have unveiled a selective loss of cholinergic neurons in the basal forebrain (Capsoni et al., 2000a) associated with a severe deficit of the cholinergic function (Rosato-Siri et al., 2006; Sola et al., 2006). Therefore, it is likely that changes in GABAergic signaling observed here are dependent on the severe deficit in nicotine cholinergic activity induced by chronic NGF deprivation.

Whatever the mechanisms, it is clear from the present experiments that NGF exerts a powerful direct or indirect (via nAChRs) control on GABAergic signaling. GABAergic excitation may at least in part counterbalance the progressive age- 
dependent Alzheimer-like neurodegenerative pathology characteristic of adult AD11 mice, thus exerting a homeostatic control on network activity.

\section{References}

Amatniek JC, Hauser WA, DelCastillo-Castaneda C, Jacobs DM, Marder K, Bell K, Albert M, Brandt J, Stern Y (2006) Incidence and predictors of seizures in patients with Alzheimer's disease. Epilepsia 47:867-872.

Ben-Ari Y (2002) Excitatory actions of gaba during development: the nature of the nurture. Nat Rev Neurosci 3:728-739.

Ben-Ari Y, Cherubini E, Corradetti R, Gaiarsa JL (1989) Giant synaptic potentials in immature rat CA3 hippocampal neurones. J Physiol 416:303325.

Ben-Ari Y, Gaiarsa JL, Tyzio R, Khazipov R (2007) GABA: a pioneer transmitter that excites immature neurons and generates primitive oscillations. Physiol Rev 87:1215-1284.

Blaesse P, Airaksinen MS, Rivera C, Kaila K (2009) Cation-chloride cotransporters and neuronal function. Neuron 61:820-838.

Capsoni S, Ugolini G, Comparini A, Ruberti F, Berardi N, Cattaneo A (2000a) Alzheimer-like neurodegeneration in aged antinerve growth factor transgenic mice. Proc Natl Acad Sci U S A 97:6826-6831.

Capsoni S, Ruberti F, Di Daniel E, Cattaneo A (2000b) Muscular dystrophy in adult and aged anti-NGF transgenic mice resembles an inclusion body myopathy. J Neurosci Res 59:553-560.

Capsoni S, Giannotta S, Cattaneo A (2002a) Nerve growth factor and galantamine ameliorate early signs of neurodegeneration in anti-nerve growth factor mice. Proc Natl Acad Sci U S A 99:12432-12437.

Capsoni S, Giannotta S, Cattaneo A (2002b) Beta-amyloid plaques in a model for sporadic Alzheimer's disease based on transgenic anti-nerve growth factor antibodies. Mol Cell Neurosci 21:15-28.

Capsoni S, Covaceuszach S, Ugolini G, Spirito F, Vignone D, Stefanini B, Amato G, Cattaneo A (2009) Delivery of NGF to the brain: intranasal versus ocular administration in anti-NGF transgenic mice. J Alzheimers Dis 16:371-388.

Cattaneo A, Rapposelli B, Calissano P (1988) Three distinct types of monoclonal antibodies after long-term immunization of rats with mouse nerve growth factor. J Neurochem 50:1003-1010.

Cattaneo A, Capsoni S, Margotti E, Righi M, Kontsekova E, Pavlik P, Filipcik P, Novak M (1999) Functional blockade of tyrosine kinase A in the rat basal forebrain by a novel antagonistic anti-receptor monoclonal antibody. J Neurosci 19:9687-9697.

Cherubini E, Gaiarsa JL, Ben-Ari Y (1991) GABA: an excitatory transmitter in early postnatal life. Trends Neurosci 14:515-519.

Cohen I, Navarro V, Clemenceau S, Baulac M, Miles R (2002) On the origin of interictal activity in human temporal lobe epilepsy in vitro. Science 298:1418-1421.

Coull JA, Beggs S, Boudreau D, Boivin D, Tsuda M, Inoue K, Gravel C, Salter MW, De Koninck Y (2005) BDNF from microglia causes the shift in neuronal anion gradient underlying neuropathic pain. Nature 438:1017-1021.

Covaceuszach S, Cassetta A, Konarev PV, Gonfloni S, Rudolph R, Svergun DI, Lamba D, Cattaneo A (2008) Dissecting NGF interactions with TrkA and 75 receptors by structural and functional studies of an anti-NGF neutralizing antibody. J Mol Biol 381:881-896.

Crowley C, Spencer SD, Nishimura MC, Chen KS, Pitts-Meek S, Armanini MP, Ling LH, McMahon SB, Shelton DL, Levinson AD, Phillips HS (1994) Mice lacking nerve growth factor display perinatal loss of sensory and sympathetic neurons yet develop basal forebrain cholinergic neurons. Cell 76:1001-1011.

Debeir T, Saragovi HU, Cuello AC (1999) A nerve growth factor mimetic TrkA antagonist causes withdrawal of cortical cholinergic boutons in the adult rat. Proc Natl Acad Sci U S A 96:4067-4072.

De Rosa R, Garcia AA, Braschi C, Capsoni S, Maffei L, Berardi N, Cattaneo A (2005) Intranasal administration of nerve growth factor (NGF) rescues recognition memory deficits in AD11 anti-NGF transgenic mice. Proc Natl Acad Sci U S A 102:3811-3816.

Dzhala VI, Talos DM, Sdrulla DA, Brumback AC, Mathews GC, Benke TA, Delpire E, Jensen FE, Staley KJ (2005) NKCC1 transporter facilitates seizures in the developing brain. Nat Med 11:1205-1213.

Fukuda A, Muramatsu K, Okabe A, Shimano Y, Hida H, Fujimoto I, Nishino $\mathrm{H}$ (1998) Changes in intracellular $\mathrm{Ca}^{2+}$ induced by GABAA receptor activation and reduction in $\mathrm{Cl}^{-}$gradient in neonatal rat neocortex. J Neurophysiol 79:439-446.

Funk K, Woitecki A, Franjic-Würtz C, Gensch T, Möhrlen F, Frings S (2008) Modulation of chloride homeostasis by inflammatory mediators in dorsal root ganglion neurons. Mol Pain 4:32-44.

Hefti F (1986) Nerve growth factor promotes survival of septal cholinergic neurons after fimbrial transactions. J Neurosci 6:2155-2162.

Huberfeld G, Wittner L, Clemenceau S, Baulac M, Kaila K, Miles R, Rivera C (2007) Perturbed chloride homeostasis and GABAergic signaling in human temporal lobe epilepsy. J Neurosci 27:9866-9873.

Kasyanov AM, Safiulina VF, Voronin LL, Cherubini E (2004) GABAmediated giant depolarizing potentials as coincidence detectors for enhancing synaptic efficacy in the developing hippocampus. Proc Natl Acad Sci U S A 101:3967-3972.

Kyrozis A, Reichling DB (1995) Perforated-patch recording with gramicidin avoids artifactual changes in intracellular chloride concentration. J Neurosci Methods 57:27-35.

Li H, Tornberg J, Kaila K, Airaksinen MS, Rivera C (2002) Patterns of cation-chloride cotransporter expression during embryonic rodent CNS development. Eur J Neurosci 16:2358-2370.

Li Y, Holtzman DM, Kromer LF, Kaplan DR, Chua-Couzens J, Clary DO, Knüsel B, Mobley WC (1995) Regulation of TrkA and ChAT expression in developing rat basal forebrain: evidence that both exogenous and endogenous NGF regulate differentiation of cholinergic neurons. J Neurosci 15:2888-2905.

Liu Z, Neff RA, Berg DK (2006) Sequential interplay of nicotinic and GABAergic signaling guides neuronal development. Science 314: $1610-1613$.

Mohajerani MH, Sivakumaran S, Zacchi P, Aguilera P, Cherubini E (2007) Correlated network activity enhances synaptic efficacy via BDNF and the ERK pathway at immature CA3 CA1 connections in the hippocampus. Proc Natl Acad Sci U S A 104:13176-13181.

Molnar M, Tongiorgi E, Avignone E, Gonfloni S, Ruberti F, Domenici L, Cattaneo A (1998) The effects of anti-nerve growth factor monoclonal antibodies on developing basal forebrain neurons are transient and reversible. Eur J Neurosci 10:3127-3140.

Nabekura J, Ueno T, Okabe A, Furuta A, Iwaki T, Shimizu-Okabe C, Fukuda A, Akaike N (2002) Reduction of KCC2 expression and $\mathrm{GABA}_{\mathrm{A}}$ receptor-mediated excitation after in vivo axonal injury. $J$ Neurosci 22:4412-4417.

Palop JJ, Mucke L (2009) Epilepsy and cognitive impairments in Alzheimer disease. Arch Neurol 66:435-440.

Palop JJ, Chin J, Roberson ED, Wang J, Thwin MT, Bien-Ly N, Yoo J, Ho KO, Yu GQ, Kreitzer A, Finkbeiner S, Noebels JL, Mucke L (2007) Aberrant excitatory neuronal activity and compensatory remodeling of inhibitory hippocampal circuits in mouse models of Alzheimer's disease. Neuron 55:697-711.

Pesavento E, Capsoni S, Domenici L, Cattaneo A (2002) Acute cholinergic rescue of synaptic plasticity in the neurodegenerating cortex of antinerve-growth-factor mice. Eur J Neurosci 15:1030-1036.

Plotkin MD, Snyder EY, Hebert SC, Delpire E (1997) Expression of the $\mathrm{Na}-\mathrm{K}-2 \mathrm{Cl}$ cotransporter is developmentally regulated in postnatal rat brains: a possible mechanism underlying GABA's excitatory role in immature brain. J Neurobiol 33:781-795.

Rheims S, Minlebaev M, Ivanov A, Represa A, Khazipov R, Holmes GL, Ben-Ari Y, Zilberter Y (2008) Excitatory GABA in rodent developing neocortex in vitro. J Neurophysiol 100:609-619.

Rivera C, Voipio J, Payne JA, Ruusuvuori E, Lahtinen H, Lamsa K, Pirvola U, Saarma M, Kaila K (1999) The $\mathrm{K}^{+} / \mathrm{Cl}^{-}$co-transporter KCC2 renders GABA hyperpolarizing during neuronal maturation. Nature 397:251255.

Rivera C, Voipio J, Kaila K (2005) Two developmental switches in GABAergic signalling: the $\mathrm{K}^{+}-\mathrm{Cl}^{-}$cotransporter KCC2 and carbonic anhydrase CAVII. J Physiol 562:27-36.

Rohrbough J, Spitzer NC (1996) Regulation of intracellular $\mathrm{Cl}^{-}$levels by $\mathrm{Na}^{+}$-dependent $\mathrm{Cl}^{-}$cotransport distinguishes depolarizing from hyperpolarizing $\mathrm{GABA}_{\mathrm{A}}$ receptor-mediated responses in spinal neurons. J Neurosci 16:82-91.

Rosato-Siri M, Cattaneo A, Cherubini E (2006) Nicotine-induced enhancement of synaptic plasticity at CA3-CA1 synapses requires GABAergic interneurons in adult anti-NGF mice. J Physiol 576:361-377.

Ruberti F, Bradbury A, Cattaneo A (1993) Cloning and expression of an 
anti-nerve growth factor (NGF) antibody for studies using the neuroantibody approach. Cell Mol Neurobiol 13:559-568.

Ruberti F, Capsoni S, Comparini A, Di Daniel E, Franzot J, Gonfloni S, Rossi G, Berardi N, Cattaneo A (2000) Phenotypic knockout of nerve growth factor in adult transgenic mice reveals severe deficits in basal forebrain cholinergic neurons, cell death in the spleen, and skeletal muscle dystrophy. J Neurosci 20:2589-2601.

Sola E, Capsoni S, Rosato-Siri M, Cattaneo A, Cherubini E (2006) Failure of nicotine-dependent enhancement of synaptic efficacy at Schaffercollateral CA1 synapses of AD11 anti-nerve growth factor transgenic mice. Eur J Neurosci 24:1252-1264.

Sun D, Murali SG (1999) $\mathrm{Na}^{+}-\mathrm{K}^{+}-2 \mathrm{Cl}^{-}$cotransporter in immature cortical neurons: a role in intracellular $\mathrm{Cl}^{-}$regulation. J Neurophysiol 81: 1939-1948.

Tyzio R, Ivanov A, Bernard C, Holmes GL, Ben-Ari Y, Khazipov R (2003)
Membrane potential of CA3 hippocampal pyramidal cells during postnatal development. J Neurophysiol 90:2964-2972.

Tyzio R, Holmes GL, Ben-Ari Y, Khazipov R (2007) Timing of the developmental switch in GABA(A) mediated signaling from excitation to inhibition in CA3 rat hippocampus using gramicidin perforated patch and extracellular recordings. Epilepsia 48:96-105.

Uvarov P, Ludwig A, Markkanen M, Pruunsild P, Kaila K, Delpire E, Timmusk T, Rivera C, Airaksinen MS (2007) A novel N-terminal isoform of the neuron-specific $\mathrm{K}-\mathrm{Cl}$ cotransporter KCC2. J Biol Chem 282:30570-30576.

van den Pol AN, Obrietan K, Chen G (1996) Excitatory actions of GABA after neuronal trauma. J Neurosci 16:4283-4292.

Yamada J, Okabe A, Toyoda H, Kilb W, Luhmann HJ, Fukuda A (2004) $\mathrm{Cl}^{-}$ uptake promoting depolarizing GABA actions in immature rat neocortical neurones is mediated by NKCC1. J Physiol 557:829-841. 